\title{
Complete microbiological analysis of citrus fruits and the effect of heat on microbial load \& antimicrobial activity
}

\author{
Sheikh Al Mamun and Farahnaaz Feroz* \\ Department of Microbiology, Stamford University Bangladesh, 51 Siddeswari Road, Dhaka 1217, Bangladesh \\ Received 18 July 2017/Accepted 16 September 2017

\begin{abstract}
Citrus fruits are very popular both for raw consumption as well as juices, jam and jelly. Besides the nutritional properties, citrus fruits exhibit some antimicrobial properties by containing polymethoxylated flavones, flavonoids, steroids, saponins, alkaloids, reducing sugars, terpenoids etc. But sometimes such fruits can be contaminated with bacteria which find their ways in the consumers causing different disease conditions. The current study revealed the microbial load of Lemon, Lotkone, Orange, Malta and Amoloki and the study showed complete absence of Klebsiella spp. and Escherichia coli. The highest total viable bacterial and fungal count was $4.2 \times 10^{4} \mathrm{cfu} / \mathrm{g}$ and $2.0 \times 10^{5} \mathrm{cfu} / \mathrm{g}$ respectively. Pseudomonas spp. was the highest predominating bacteria with lower degree of contamination by Listeria spp. and Staphylococcus spp. Applying heat at $60{ }^{\circ} \mathrm{C}$ for 30 minutes, 1 hour and 2 hours proved the reduction of bacteria over time. Antibacterial activity after heat treatment for all cases (after 30 minutes, 1 hour and 2 hours). Antibacterial activity was lowest after 2 hours of heat treatment for amoloki and there was no such activity at all for Amra after 2 hours. Other citrus fruits surprisingly showed no antibacterial activity after heat treatment.
\end{abstract}

Key words: Citrus fruits, Microbial load, Antibacterial activity, Heat treatment

Citrus fruits possess microbiological contamination and contribute to an increase in the rate of infectious disease $(1,2)$. Common contaminants include Escherichia coli, Salmonella spp., Listeria monocytogenes, Aeromonas spp., Staphylococcus spp., Streptococcus spp., Vibrio spp., Pseudomonas spp., all of which serve as a threat to public health (2-4). Citrus fruits consists of various beneficial nutrient content such as minerals, energy, fiber content, ascorbic acid, folate, potassium, phytochemicals etc. (5-10) Different reports have verified the antimicrobial activity of fruits to be efficient against various infections including enteritis, arthritis, cardiac complications, etc. (3, 9-12).

Bacterial \& Fungus may be transmitted through citrus fruits (13). Increase in popularity can also be attributed to government campaigns promoting the consumption of fruits and vegetables (14). Fruits play important roles against cardiovascular \& cancerous disease (4). Fruits contain antioxidants which help protect cells and tissues from free radicals, while contributing to the proper functioning of DNA repair mechanisms, digestion, cell metabolism etc. (15). Countries such as Iran has seen an increase in the purchase of fresh fruits (16). Various European countries have also realized the same trend in consumption (3). The nutritional benefits account for

*Corresponding Author: Mailing address. Dr. Farahnaaz Feroz, Assistant Professor, Department of Microbiology, Stamford University Bangladesh, 51 Siddeswari Road, Dhaka 1217, Bangladesh, Bangladesh; E-mail: farahnaaz@stamforduniversity.edu.bd. majority of consumers relying on fruits as a source of vitamins (2). Even with all the benefits, factors such as mishandling during storage, transportation and insufficient preparation propagated the spread of foodborne diseases $(16,17)$. Use of non-performed medicines, inefficiencies in waste management, lack of studies in antibacterial treatment of foods and relatively poor management of healthcare system have contributed to the development of a major health care issue in the food chain $(13-15,17)$. Researchers and scientists have also applied several sterilization methods to reduce the microbial load such as pressure and heat treatments, which include hot water, vapor heat or hot air treatments (13).

Current study attempted to identify the microbiological loads of citrus fruits, collected from Dhaka City, Bangladesh and to elucidate the effect of heat on the microorganisms, in an attempt to set up heat as an operative, low cost and easy to use method of sterilization .The current study also describe the antimicrobial activity of the citrus fruits and whether heat will affect its actions.

\section{MATERIALS AND METHODS}

\footnotetext{
Samples. Six different raw citrus fruits (Lemon, Amoloki, Amra, Orange, Lotkone and Malta) were collected from public roadside markets early in the morning. All samples were instantly shifted to the Microbiological Laboratory at Stamford University, Bangladesh, Dhaka and subjected to microbiological investigation.

Total bacterial and fungal analysis. Total bacterial and fungal analysis was carried out as mentioned in Feroz et al. (18). Ten grams of the sample was homogenized for $1 \mathrm{~min}$ in sterilized $90 \mathrm{ml}$ of physiological saline using a
} 
stomacher (Model No. 061-21001; Atect Co. Ltd, Japan). From this homogenate, serial dilutions were arrayed and surface plated $(0.1 \mathrm{ml}$, in duplicate) on Nutrient Agar (NA) and Sabaroud Dextrose Agar (SDA). NA plates were incubated at $37{ }^{\circ} \mathrm{C}$ for 48 hours, while the SDA plates were incubated at $25{ }^{\circ} \mathrm{C}$ for 5 days. After incubation, the bacterial counts and fungal counts per gram were considered from NA plates and SDA plates, gradually (18-20)

Identification of coliform bacteria. From the dilution $10^{-2} \& 10^{-3}$, the $0.1 \mathrm{ml}$ sample was spread onto MacConkey agar for the detection of total coliform. The plates were incubated at $37^{\circ} \mathrm{C}$ for 24 hours.

Identification of Pseudomonas spp. and Staphylococcus spp. and Listeria spp. Staphylococcus spp., Pseudomonas spp. and Listeria spp. were identified from the Mannitol Salt Agar (MSA), Pseudomonas agar and Listeria identification media respectively after spreading $0.1 \mathrm{ml}$ of the diluted samples on these media. Results were observed after 24 hours incubation at $37{ }^{\circ} \mathrm{C}$.

Determining Antimicrobial Activity. Determination of anti-bacterial activity was performed by using the agar well diffusion method as previously described $(2,3,17,21)$. Culture suspensions of 9 laboratory bacterial strains (Bacillus spp., Pseudomonas spp., Vibrio spp., Escherichia coli, Klebsiella spp., Staphylococcus spp., Listeria spp., Salmonella spp., and Aeromonas spp.) were prepared in normal saline equivalent with the turbidity of the McFarland standard. Each of the test bacterial lawn was made by separately spreading evenly over the separate Muller-Hinton agar (MHA). Wells with volumes of 8 $\mathrm{mm}^{3}$ were made through the MHA $(17,21)$. Each of the crashed fruit blends $(100 \mu \mathrm{l})$ was added to the wells along with the disc of gentamicin $10 \mu \mathrm{g}$ as the positive control and an aliquot of $100 \mu 1$ normal saline was used as the negative control. After drying the plates were then incubated at $37^{\circ} \mathrm{C}$ for $12-18$ hours.

Effect of Heat on microbial and fungal growth. Samples were transferred into the sterilizer at $60{ }^{\circ} \mathrm{C}$ for 3 intervals via 30 minutes, 1 hour and 2 hours (18). After treatment, total bacterial counts and total fungal counts, as well as antimicrobial activity was determined by the methods mentioned above $(2,3$, 17, 21).

\section{RESULTS AND DISCUSSION}

Five different citrus fruits (Lotkone, Lemon, Orange, Amoloki, Amra and Malta) were subjected for microbiological analysis in this current study. Malta showed the highest load of total viable bacterial count $\left(4.2 \times 10^{4} \mathrm{cfu} / \mathrm{g}\right)$ whereas other citrus samples showed nearly similar results ranging from $1.7 \times 10^{3} \mathrm{cfu} / \mathrm{g}$ to $6.6 \times 10^{3} \mathrm{cfu} / \mathrm{g}$. Total fungal count was found to be highest in orange $\left(2.0 \times 10^{5} \mathrm{cfu} / \mathrm{gm}\right)$ and lowest in amra $\left(1.3 \times 10^{3} \mathrm{cfu} / \mathrm{g}\right)$. Coliform bacteria Escherichia coli and Klebsiella spp. were absent in all of these five selected samples. Pseudomonas spp. was also found in all the samples ranging from $7.5 \times 10^{4} \mathrm{cfu} / \mathrm{g}$ in Amra to $1.1 \times 10^{2}$ cfu/g in bv malta. Staphylococcus spp. and Listeria spp. were found in less quantity compared to other bacteria. Lowest Staphyloccus spp. count was observed in orange $\left(1.6 \times 10^{1} \mathrm{cfu} / \mathrm{g}\right)$ and two citrus fruits were free from Listeria spp. (lemon and orange). All of the citrus fruit samples showed nearly similar results except orange which showed greater degree of fungal growth than other samples. Overall, fungal growth might be responsible for the presence of mycotoxin if not washed thoroughly before consumption or using for making juices $(22,23)$. Orange provides the most acidic condition among the other fruits which encouraged the growth of fungus. No growth of coliform bacteria indicates that the fruits were out of reach of the faecally contaminated water. Being an indigenous bacteria, Pseudomonas spp. can be found in every types of products and so the samples are also reflecting the same condition. But the actual growth of Pseudomonas spp. is higher than any other bacteria. Pseudomonas spp. and Listeria spp. are able to spread enteric disease amonth the people who consumes these fruits without maintenance of proper hygiene $(22,23)$.

Amoloki, Lotkone, Amra, Lemon, Malta and Orange, all showed similar results after heat treatment at $60{ }^{\circ} \mathrm{C}$. Heat exposure was done for 30 minutes, 1 hour and 2 hours for all samples and then microbiological analysis was done again to determine the degree of reduction of bacteria which we found during the first microbiological test procedure of this study (Tables 2-7). In general, a decrease in microbial and fungal growth was observed as a result of heat treatment. Increased time of treatment corresponded with increased microbial and fungal growth reduction. Heat application did not result in regrowth of eliminated microorganisms or serve as a initiator of growth for originally absent microorganisms. For Amoloki, we found complete reduction of Listeria spp. and total fungal count after 2 hours of heat treatment (Table 2). In case of Lotkone, total fungal count, Listeria spp. and Staphylococcus spp. were killed by $100 \%$ after 2 hours of treatment (Table 3). Same results have been found for Orange, Malta and Amra (Tables 4, 6, 7). In case of Amra, total fungal count was reduced complete after 30 minutes of heat exposure unlike other samples

TABLE 1. Microbial load of different citrus fruits samples.

\begin{tabular}{cccccccc}
\hline & \multicolumn{6}{c}{ Microbial load (cfu/g) } \\
\cline { 2 - 7 } Sample & TVB & TF & E. coli & $\begin{array}{c}\text { Klebsiella } \\
\text { spp. }\end{array}$ & $\begin{array}{c}\text { Pseudomonas } \\
\text { spp. }\end{array}$ & $\begin{array}{c}\text { Staphylocccus } \\
\text { spp. }\end{array}$ & Listeria spp. \\
\hline Lotkone & $4.8 \times 10^{3}$ & $7.3 \times 10^{3}$ & 0 & 0 & $2.4 \times 10^{4}$ & $6.8 \times 10^{1}$ & $6.7 \times 10^{2}$ \\
Lemon & $1.6 \times 10^{3}$ & $2.8 \times 10^{3}$ & 0 & 0 & $2.7 \times 10^{4}$ & $2.3 \times 10^{1}$ & 0 \\
Orange & $1.7 \times 10^{3}$ & $2.0 \times 10^{5}$ & 0 & 0 & $4.4 \times 10^{3}$ & $1.6 \times 10^{1}$ & 0 \\
Amloki & $6.6 \times 10^{3}$ & $8.1 \times 10^{3}$ & 0 & 0 & $2.1 \times 10^{3}$ & $3.2 \times 10^{1}$ & $6.8 \times 10^{2}$ \\
Amra & $3.2 \times 10^{3}$ & $1.3 \times 10^{3}$ & 0 & 0 & $7.5 \times 10^{4}$ & $6.5 \times 10^{3}$ & $1.0 \times 10^{2}$ \\
Malta & $4.2 \times 10^{4}$ & $8.0 \times 10^{4}$ & 0 & 0 & $1.1 \times 10^{2}$ & $1.2 \times 10^{3}$ & $1.3 \times 10^{2}$ \\
\hline
\end{tabular}

$\mathrm{TVB}=$ Total viable bacteria $; \mathrm{TF}=$ Total fungi 
TABLE 2. Effect of heat on Amloki.

\begin{tabular}{cccccc}
\hline & \multicolumn{5}{c}{ Microbial load (cfu/g) } \\
\cline { 2 - 6 } Temperature Used & TVB & TF & $\begin{array}{c}\text { Pseudomonas } \\
\text { spp. }\end{array}$ & $\begin{array}{c}\text { Staphylococcus } \\
\text { spp. }\end{array}$ & $\begin{array}{c}\text { Listeria } \\
\text { spp. }\end{array}$ \\
\hline 30 Minutes & $4.3 \times 10^{3}$ & $6.1 \times 10^{2}$ & $8.0 \times 10^{2}$ & $5.2 \times 10^{2}$ & $4.2 \times 10^{2}$ \\
1 Hour & $3.2 \times 10^{2}$ & $3.6 \times 10^{3}$ & $7.2 \times 10^{2}$ & $8.5 \times 10^{1}$ & $3.1 \times 10^{1}$ \\
2 Hours & $2.8 \times 10^{2}$ & 0 & $5.6 \times 10^{2}$ & $3.1 \times 10^{1}$ & 0 \\
\hline
\end{tabular}

$\mathrm{TVB}=$ Total viable bacteria; $\mathrm{TF}=$ Total fungi

TABLE 3. Effect of heat on Lotkone.

\begin{tabular}{cccccc}
\hline & \multicolumn{5}{c}{ Microbial load (cfu/g) } \\
\cline { 2 - 6 } Temperature Used & TVB & TF & $\begin{array}{c}\text { Pseudomonas } \\
\text { spp. }\end{array}$ & $\begin{array}{c}\text { Staphylococcus } \\
\text { spp. }\end{array}$ & $\begin{array}{c}\text { Listeria } \\
\text { spp. }\end{array}$ \\
\hline 30 Minutes & $3.2 \times 10^{3}$ & $6.9 \times 10^{3}$ & $7.6 \times 10^{2}$ & $5.8 \times 10^{2}$ & $5.5 \times 10^{1}$ \\
1 Hour & $2.8 \times 10^{3}$ & $5.4 \times 10^{1}$ & $6.4 \times 10^{1}$ & $4.7 \times 10^{1}$ & $4.3 \times 10^{1}$ \\
2 Hours & $2.1 \times 10^{2}$ & 0 & $5.7 \times 10^{1}$ & 0 & 0 \\
\hline
\end{tabular}

$\mathrm{TVB}=$ Total viable bacteria; $\mathrm{TF}=$ Total fungi

TABLE 4. Effect of heat on Amra.

\begin{tabular}{cccccc}
\hline \multirow{2}{*}{ Temperature Used } & \multicolumn{5}{c}{ Microbial load (cfu/g) } \\
\cline { 2 - 6 } & TVB & TF & $\begin{array}{c}\text { Pseudomonas } \\
\text { spp. }\end{array}$ & $\begin{array}{c}\text { Staphylococcus } \\
\text { spp. }\end{array}$ & $\begin{array}{c}\text { Listeria } \\
\text { spp. }\end{array}$ \\
\hline 30 Minutes & $2.4 \times 10^{3}$ & 0 & $3.3 \times 10^{2}$ & $1.8 \times 10^{2}$ & $2.6 \times 10^{1}$ \\
1 Hour & $1.6 \times 10^{3}$ & 0 & $2.6 \times 10^{2}$ & $1.6 \times 10^{1}$ & $1.7 \times 10^{1}$ \\
2 Hours & $1.2 \times 10^{2}$ & 0 & $1.5 \times 10^{2}$ & 0 & 0 \\
\hline
\end{tabular}

$\mathrm{TVB}=$ Total viable bacteria; $\mathrm{TF}=$ Total fungi

TABLE 5. Effect of heat on Lemon.

\begin{tabular}{cccccc}
\hline \multirow{2}{*}{ Temperature Used } & \multicolumn{5}{c}{ Microbial load (cfu/g) } \\
\cline { 2 - 6 } & TVB & TF & $\begin{array}{c}\text { Pseudomonas } \\
\text { spp. }\end{array}$ & $\begin{array}{c}\text { Staphylococcus } \\
\text { spp. }\end{array}$ & $\begin{array}{c}\text { Listeria } \\
\text { spp. }\end{array}$ \\
\hline 30 Minutes & $3.6 \times 10^{3}$ & $3.1 \times 10^{2}$ & $1.5 \times 10^{1}$ & $1.2 \times 10^{1}$ & $2.2 \times 10^{1}$ \\
1 Hour & $3.2 \times 10^{2}$ & 0 & 0 & 0 & 0 \\
2 Hours & $2.8 \times 10^{2}$ & 0 & 0 & 0 & 0 \\
\hline
\end{tabular}

$\mathrm{TVB}=$ Total viable bacteria; $\mathrm{TF}=$ Total fungi

(Table 4). Pseudomonas spp. was completely eradicated only in lemon (Table 5). Heat treatment at $60{ }^{\circ} \mathrm{C}$ was effective for fungi, Staphylococcus spp. and Listeria spp. after 2 hours of heat treatment. But total viable bacterial count was reduced but the reduction was not as much as other bacteria and fungi. This indicates the presence of thermophilic bacteria in these citrus fruits which might be difficult to reduce by further heat treatment. In this study study we used $60{ }^{\circ} \mathrm{C}$ temperature, a condition at which many bacteria can not be killed, instead they occupy resistance because of such selective pressure rendering them to withstand such condition. Exposure to higher temperature might reduce these bacteria more than using $60{ }^{\circ} \mathrm{C}$.

Lotkon, Malta, Lemon and Orange showed no antimicrobial activity against Staphylococcus spp., 
TABLE 6. Effect of heat on Malta.

\begin{tabular}{ccccccc}
\hline & \multicolumn{5}{c}{ Microbial load (cfu/g) } \\
\cline { 2 - 6 } Temperature Used & TVB & TF & $\begin{array}{c}\text { Pseudomonas } \\
\text { spp. }\end{array}$ & $\begin{array}{c}\text { Staphylococcus } \\
\text { spp. }\end{array}$ & $\begin{array}{c}\text { Listeria } \\
\text { spp. }\end{array}$ \\
\hline 30 Minutes & $4.6 \times 10^{3}$ & $2.6 \times 10^{2}$ & $2.2 \times 10^{2}$ & $2.6 \times 10^{1}$ & $2.8 \times 10^{2}$ \\
1 Hour & $3.8 \times 10^{3}$ & 0 & $1.6 \times 10^{1}$ & $1.8 \times 10^{1}$ & 0 \\
$\mathbf{2}$ Hours & $2.9 \times 10^{2}$ & 0 & $1.1 \times 10^{1}$ & 0 & 0 \\
\hline
\end{tabular}

$\mathrm{TVB}=$ Total viable bacteria $\mathrm{TF}=$ Total fungi

TABLE 7. Effect of heat on Orange.

\begin{tabular}{cccccc}
\hline \multirow{2}{*}{ Temperature Used } & \multicolumn{5}{c}{ Microbial load (cfu/g) } \\
\cline { 2 - 6 } & TVB & TF & $\begin{array}{c}\text { Pseudomonas } \\
\text { spp. }\end{array}$ & $\begin{array}{c}\text { Staphylococcus } \\
\text { spp. }\end{array}$ & $\begin{array}{c}\text { Listeria } \\
\text { spp. }\end{array}$ \\
\hline 30 Minutes & $4.7 \times 10^{3}$ & $4.3 \times 10^{2}$ & $8 \times 10^{2}$ & $4.2 \times 10^{1}$ & $2.2 \times 10^{1}$ \\
1 Hour & $3.7 \times 10^{3}$ & $3.7 \times 10^{1}$ & $5 \times 10^{2}$ & $1.1 \times 10^{1}$ & $1.1 \times 10^{1}$ \\
2 Hours & $2.9 \times 10^{2}$ & 0 & $2 \times 10^{1}$ & 0 & 0 \\
\hline
\end{tabular}

$\mathrm{TVB}=$ Total viable bacteria $; \mathrm{TF}=$ Total fungi

TABLE 8. Antimicrobial activity of Amra.

\begin{tabular}{cccccc}
\hline Temperature & $\begin{array}{c}\text { Staphylococcus } \\
\text { spp. }\end{array}$ & $\begin{array}{c}\text { Fungal } \\
\text { count }\end{array}$ & $\begin{array}{c}\text { Klebsiella } \\
\text { spp. }\end{array}$ & $\begin{array}{c}\text { Pseudomonas } \\
\text { spp. }\end{array}$ & $\begin{array}{c}\text { Listeria } \\
\text { spp. }\end{array}$ \\
\hline 30 minutes & $30 \mathrm{~mm}$ & 0 & $17 \mathrm{~mm}$ & 0 & 0 \\
$\mathbf{1}$ hour & $30 \mathrm{~mm}$ & 0 & $17 \mathrm{~mm}$ & 0 & 0 \\
$\mathbf{2}$ hours & 0 & 0 & 0 & 0 & 0 \\
\hline
\end{tabular}

TABLE 9: Antimicrobial activity of Amloki.

\begin{tabular}{cccccc}
\hline Temperature & $\begin{array}{c}\text { Staphylococcus } \\
\text { spp. }\end{array}$ & $\begin{array}{c}\text { Fungal } \\
\text { count }\end{array}$ & $\begin{array}{c}\text { Klebsiella } \\
\text { spp. }\end{array}$ & $\begin{array}{c}\text { Pseudomonas } \\
\text { spp. }\end{array}$ & $\begin{array}{c}\text { Listeria } \\
\text { spp. }\end{array}$ \\
\hline 30 minutes & $26 \mathrm{~mm}$ & $23 \mathrm{~mm}$ & $24 \mathrm{~mm}$ & $27 \mathrm{~mm}$ & $24 \mathrm{~mm}$ \\
$\mathbf{1}$ hour & $24 \mathrm{~mm}$ & $22 \mathrm{~mm}$ & $23 \mathrm{~mm}$ & $26 \mathrm{~mm}$ & $23 \mathrm{~mm}$ \\
2 hours & $22 \mathrm{~mm}$ & $20 \mathrm{~mm}$ & $21 \mathrm{~mm}$ & $24 \mathrm{~mm}$ & $21 \mathrm{~mm}$ \\
\hline
\end{tabular}

Klebsiella spp., Pseudomonas spp., Listeria spp. and fungi after heat treatment at different exposure times like 30 minutes, 1 hour and 2 hours (Tables $8 \& 9$ ). The antimicrobial activity might be destroyed or inactivated after heat treatment. Use of heat imparted no adverse effects on the antimicrobial activity of Amra and Amoloki asserting its effectiveness in use as a disinfecting method without affecting food quality. Additionally, many citrus fruits, traditionally thought to possess antimicrobial activity, failed to express adequate activity. Rising rate of food borne illnesses make studies into adequate methods of decontaminating foods imperative, in order to retain the health of the society. The use of heat on foods would protect the quality of the foods without affecting nutritional benefits or affecting the profit margins of the food production and/or agricultural companies. Its application will greatly improve the quality of the foods, particularly as it is a non-chemical method of sterilization.

\section{CONCLUSION}

Overall, the findings of this study clearly indicate a complete bacteriological profile of local market citrus fruits, which is of public health significance. Further studies with some advanced molecular settings for the 
better detection of the pathogens as well as some good solvent extraction methods need to be established to use citrus fruits as a potential therapeutic agent which may reduce the use of conventional drugs for the remedy of various diseases.

\section{REFERENCES}

1. Dharmishtha M, Falguni G. 2009. Antibacterial activity of methanolic fruit extract of randia dumetrum lamk. Int J Pharm Tech Resl. 1: 679-681.

2. Hoque MDM, Bari ML, Inatsu Y, Juneja VK, Kawamoto S. 2007 Antibacterial activity of guava (Psidium guajava L.) and neem (Azadirachta A. Juss) extracts against foodborne pathogens and spoilage bacteria. Foodborne pathog Dis, 4: 481-488.

3. Fadipe LA, Haruna K, Mohammed I, Ibikune GF. 2013. Phytochemical and in-vitro antibacterial evaluation of the extracts, portions and sub-portions of the ripe and unripe fruits of Nauclea latifolia. J Med Plants Res. 7:629-636.

4. Sivapriya M, Harsha DR, Gowda SST, Srinivas L. 2011. Antibacterial Activity of Different Extracts of Sundakai (Solanum torvum) Fruit Coat. Int J Biol Chem. 5: 61-67.

5. Jelodarian S, Ebrahimabadi AH, Kashi FJ. 2013. Evaluation of antimicrobial activity of Malus domestica fruit extract from Kashan area. Avicenna J Phytomed. 3: 1-6.

6. Prakas P, Kumar N. 2013. Design and development of sustained reease matris tablet of diclofena sodium using natural polymer. Int Res J Pharm. 4: 169-176.

7. Sibi G, Kaushik K, Dhananjaya K, Ravikumar KR, Mallesha H. 2013. Antibacterial activity of Sechium edule (Jacq.) Swartz against Gram negative food borne bacteria. Adv Appl Sci Res. 4: 259-261.

8. Ghasemi P, Momeni A, Bahmani M. 2013. Ethnobotanical study of medicinal plants used by Kurd tribe in Dehloran and Abdanan districts. Ilam Provinve, Iran. Afr J Trad Complement Altern Med. 10: 368-385.

9. Umer A, Tekewe A, Kebede N. 2013. Antidiarrhoel and antimicrobial activity of Calpurnia aurea leaf extract. BMC Complemen Altern Med. 13: 21.

10. Naseer U, Hajera T, Ali MN, Ponia K. 2012. Evaluation of antibacterial activity of five selected fruits on bacterial wound isolates. Int J Pharma Bio Sci. 3: 531-546.
11. Iwu MW, Duncan A and Okunji CO. 1999. New antimicrobials of plant origin. In: Janick J. Editor. Perspectives on new crops and new uses, ASHS Press, Alexandria.

12. Chanda S, Baravalia Y, Kaneria M, Rakholiya K. 2010. Fruit and vegetable peels - strong natural source of antimicrobics. Current Res Technol Edu Topics Appl Microbiol Microbial Biotechnol. 35: 444-450.

13. Yoon JY, Kim B. 2012. Lab-On-Chip Pathogen Sensors for food Safety. Sensors 12: 10713-10741.

14. Abadias M, Usall J, Anguera M, Solsona C, Viñas I. 2008. Microbiological quality of fresh, minimally- processes fruit and vegetables and sprouts from retail establishments. Int. J. Food Microbiol. 123: 121-129.

15. Caradamone C, Aleo A, Mammina C, Oliveri G, Di Noto AM. 2015. Assesment of the microbiological quality of fresh produce on sale in Sicily, Italy: preliminary results. J. Biol. Res. Thessaloniki. 22:3.

16. Jeddi MZ, Yunesian M, Gorji ME, Noori N, Pourmad MR, Khaniki GRJ. 2014. Microbial Evalutaion of Fresh, Minimally- processed Vegetables and Bagged Sprouts from Chain Supermarkets. J. Health Popul. Nutr. 32 (3): 391-399.

17. Akter R, Tanu NI, Uddin A. 2013 Isolation and quatification of bacterial isolates from citrus fruits and determination of their antibacterial activity against selected pathogens. Stamford J. Microbiol. 3 (1): 30-33.

18. Feroz F, Mori M, Sakagami Y. 2016. Bacterial and fungal loads in raw sea foods, fruits and vegetables collected from Dhaka Bangladesh and the effect of heat on its growth, Bangladesh J. Microbiol. 33 (1-2), 23-28.

19. Alam MS, Feroz F, Rahman H, Das KK and Noor R. 2015. Microbiological contamination sources of freshly cultivated vegetables. Nutr. and Food Sci. 44(4): 646- 658.

20. Rahman H, Feroz F, Alam MS, Das KK, Noor R. 2016. Demonstration of the source of microbial contamination of freshly cultivated cabbage, cauliflower, potato and squash collected from rural farms of Bangladesh. Int. Food Res. J. 23 (3): 1289-1295.

21. Tahera J, Feroz F, Senjuti JD, Das KK, Noor R. 2014. Demonstration of Anti-Bacterial Activity of commonly available Fruit Extracts in Dhaka, Bangladesh. American Journal of Microbiological Research. 2 (2): 68-73.

22. Reddy KRN. 2010. An overview of mycotoxin contamination in foods and its implications for human health. Toxin Reviews. 29 (1): 3-26.

23. Shephard GS. 2008. Impact of mycotoxins on human health in developing countries. Food Addit Contam. 25 (2):146-51. 